\title{
Mud volcanoes in the South Caspian basin: Nature and estimated depth of its products
}

\author{
Akper A. Feyzullayev \\ Geology Institute of the Azerbaijan National Academy of Sciences, Baku, Azerbaijan; fakper@gmail.com
}

Received 24 April 2012; revised 26 May 2012; accepted 14 June 2012

\section{ABSTRACT}

In paper based on the results of previous studies and latest investigations of mud volcanoes in the South Caspian basin the depth occurrence of fluid, mud and rocks are calculated and modeled. Major factors causing formation of diapirism/mud volcanism in the South Caspian basin are Pliocene-Quaternary high sedimentation rates (up to $3 \mathrm{~km} / \mathrm{my}$ ), super thick sedimentary cover (up to $25-30 \mathrm{~km}$ ), predominance of clayey rocks (reaching $80 \%$ ) in the section, low temperatures (with $15^{\circ} \mathrm{C}-18^{\circ} \mathrm{C} / \mathrm{km}$ gradient), overpressures reaching lithostatic, the onset of petroleum generation lowered to considerable depths. The majority of the mud volcanoes are associated with the petroleum bearing structures. Depths where the liquid, gaseous and solid products of mud volcanoes are sourced appear to be different. The gases have the deepest roots $(7-15 \mathrm{~km})$ which are the main force in formation and activity of MVs. Source of the fluidized clayey mass does not lie below $3-4 \mathrm{~km}$. Oils emitted by mud volcanoes are the product of destruction of petroleum accumulations occurring beneath them.

Keywords: Mud Volcano; Fluid; Geochemistry; Temperature; Depth; South Caspian Basin

\section{INTRODUCTION}

Many years of study of mud volcanoes (MVs) in Azerbaijan has led to revealing main regularities in their distribution, morphological patterns, activity characteristics, as well as compositional properties of their products (breccia, rock fragments, gas, oil, water) and also character of their reflection in geophysical fields were discovered [1-5, etc.].

Remarkable achievements in studies of Azerbaijan mud volcanoes using modern geophysical, geochemical and other methods were obtained during the last two dec- ades [6-16, etc].

This will promote better understanding of the conditions and mechanism of their formation.

The petroleum bearing South Caspian basin ( $\mathrm{SCB}$ ) is located within the Alpine-Himalayan mobile tectonic belt where earthquakes and intense modern earth's crust movements have been observed. SCB is a relic of the Tethys Ocean originated in the post orogenic stage of the regional development. It is typically intermountain basin surrounded by mountain systems: Great and Lesser Caucasus, Talysh, Elburs, Kopetdag and Balkhan (Figure 1).

The present-day structure of SCB is still controlled by the ongoing collision of the Arabian and Russian plates [17-19]. The orogeny during the Oligocene, continuing up to now and causing a large area, is dominated by right lateral strike slip deformation [20] and reactivation of many of the earlier extensional faults, which resulted in weakening of the overburden sediments.

The main geological peculiarities of the $\mathrm{SCB}$, some of which are unique are the following:

1) Very rapid Pliocene-Quaternary subsidence and

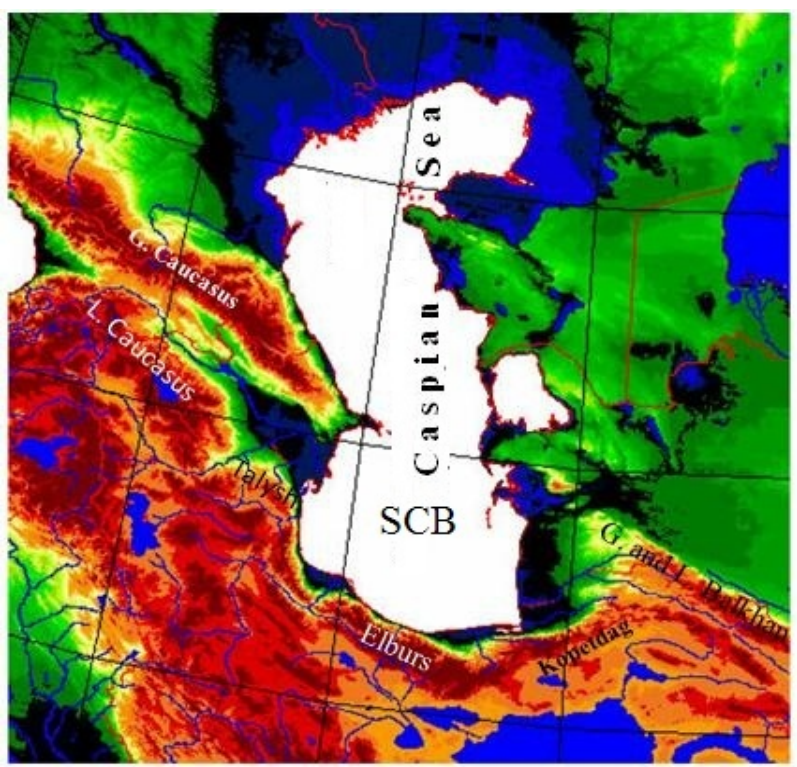

Figure 1. Morphology and position of the SCB. 
sedimentation rate (in average about $2 \mathrm{~km} / \mathrm{Ma}$ ). Over $80 \%$ of these sediments consist of clayey rocks;

2) The thickness of the sedimentary cover (MesozoicCenozoic) is $25-30 \mathrm{~km}$ and has no analogues in the world (Figure 2);

3) Characteristic the split-level structure of the sedimentary section in SCB, including the upper Paleogene-Quarternary complex presented mainly by plastic (undercompacted and decompacted) rocks and the lower Mesozoic, consisting of the dense rocks;

4) Anomalous low temperature regime: heat flow$(25-51) \mathrm{mW} / \mathrm{m} . \mathrm{sq}$., temperature gradient $-15^{\circ} \mathrm{C}-18^{\circ} \mathrm{C} /$ $\mathrm{km}$;
5) Displacement of the onset of oil generation on considerable depths (oil to 4 - $5 \mathrm{~km}$, gas to $7 \mathrm{~km}$ ) (see Figure 2);

6) High recent geodynamic activity: horizontal and vertical movements of Earth crust and shallow seismicity. Within the SCB tens of earthquakes with different magnitude are annually recorded. It is necessary to mention that most earthquakes have shallow focus which do not exceed 10 - $15 \mathrm{~km}$ (Figure 3).

All above-mentioned geological factors contribute to formation and activity of diapirs/mud volcanoes.

In spite of achieved successes, scientists continue to argue about the origin of this amazing phenomenon.

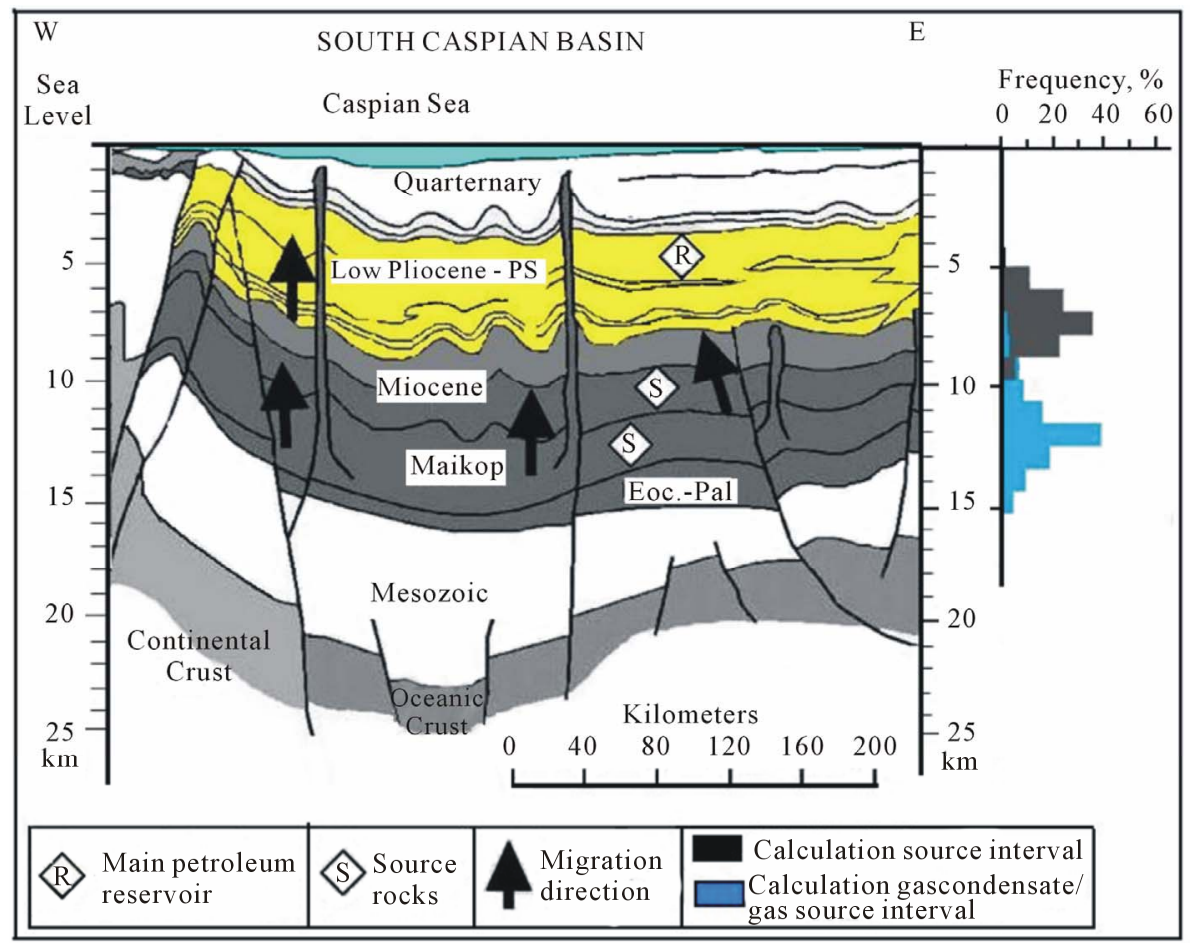

Figure 2. Regional geological profile along Caspian Sea and location in the sedimentary.

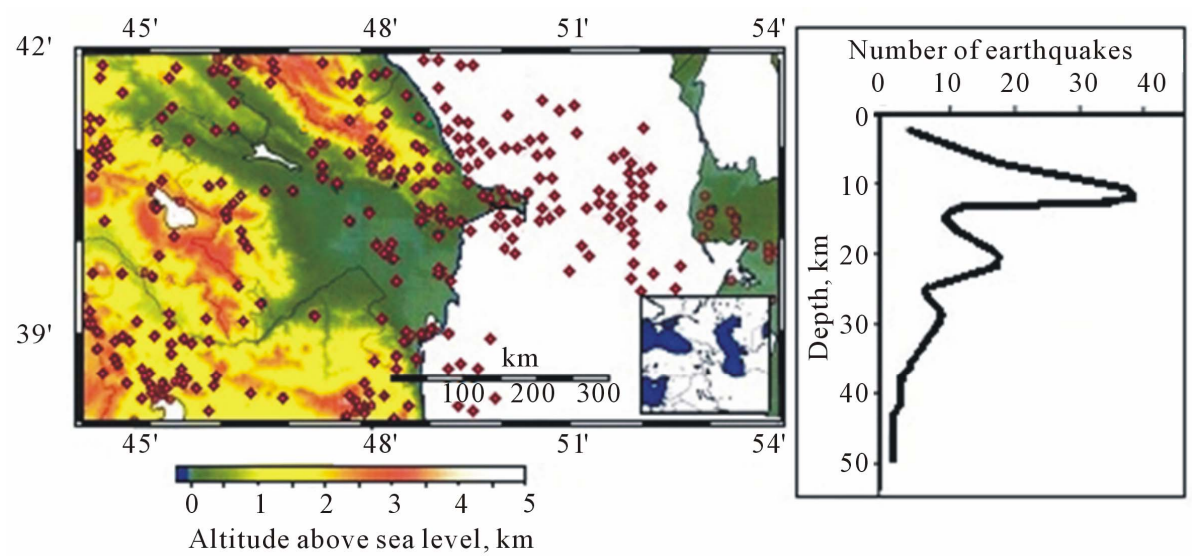

Figure 3. Distribution in SCB of the earthquakes events with magnitude $M \geq 4$ and earthquakes hypocenters vs depth. 
Some suggest that the process takes place wholly within the sedimentary succession [1,14,21], whereas others envisage a connection with the deeper processes operating within the mantle [3]. Therefore results of estimation of the depth occurrence of the MVs products in SCB are presented in this paper.

\section{INVESTIGATION APPROACH}

A number of isotopic-geochemical parameters are applied for direct assessments of oil and hydrocarbon gas maturity $[22,23]$.

\subsection{The Gas Maturity}

The gas maturity estimates were made using experimentally established interrelation between isotopic composition of carbon in ethane and vitrinite reflectance $\left(R_{0}\right.$, $\%$ ) [22]. Methane carbon isotopic signatures are less reliable in view of possible bacterial methane input. Using this relation in combination with the $R_{o}$ versus depth change in the SCB depths of HC gas source are evaluated.

\subsection{The Oil Maturity}

Sterane isomerisation degree $\{\alpha \alpha \alpha \mathrm{C} 29(20 \mathrm{~S} / \mathrm{S}+\mathrm{R})\}$, monoaromatic sterane aromatization degree \{C28triaromatic sterane/C28triarom. + C29monoaromatic sterane $\}$ and methyl-phenantrene index fformulae MPI $-1=(1.5$ $(2-\mathrm{MP}+3-\mathrm{MP})) /(\mathrm{P}+1-\mathrm{MP}+9-\mathrm{MP}+4-\mathrm{MP})$ and are most often applied biomarker ratios for oil maturity assessments. Based on empirically derived relationships values of these parameters are converted to equivalent vitrinite reflectance values $\left(R_{e q}\right)$. In this study for oil maturity assessment MPI - 1 parameter was used [23].

For estimation of the depth occurrences of mud, water and rock-ejects the complex data (recent and paleo-temperatures, seismic records, geological section, etc.) were applied.

\section{RESULTS AND DISCUSSION}

\subsection{Estimation of Depth of the Liquid and Solid Products of MVs}

MVs emit the fluids and mud during both dormant and explosive activity. The nature of its products is great scientific interest. Based on the isotopic composition of helium [2] argon and carbon in methane [6,9] the Azerbaijan mud volcanoes have a sedimentary origin and they are products of different stages of a single process of hydrocarbon generation within the sedimentary succession. The chemical and isotopic signatures of MV gases are predominantly thermogenic with some admixture of microbial methane [14].

Based on the isotopic composition of the $\mathrm{C}_{1}$ to $\mathrm{C}_{4}$, that the hydrocarbon gases on the Regnano mud volcano (northern Italy) have a thermogenic origin and they were formed by thermal cracking $\left(>150^{\circ} \mathrm{C}\right)$ [24]. They are later products of oil and/or kerogen alterations in overmature environments [25].

The results of determination of the hypsometric and stratigraphic source of liquid and solid products of MVs in the SCB are given below.

\subsubsection{Gas}

Calculated gas maturity values (at the vitrinite reflectance equivalent -Req.) vary between $1.2 \%-2.0 \%$, corresponding to the depth interval of $10-16 \mathrm{~km}$ (peak - to $11-12 \mathrm{~km})$. On MVs are almost absent low mature gases (less than 1.4\% Req.) in comparison with reservoir gases (Figure 4). Except one mud volcano (Zaakhtarma), gases of all studied MVs refer to gas-condensate-wet gas zone.

It is established dependence between isotope composition of helium and calculated maturity of gases of the Azerbaijan mud volcanoes (Table 1).

There is a direct relationship between $\mathrm{ICC}$ of $\mathrm{CH}_{4}$ and ${ }^{40} \mathrm{Ar} /{ }^{36} \mathrm{Ar}$ values too, reflecting consistent increase of gas maturity with increasing of age of rocks (Figure 5).

ICC of $\mathrm{CO}_{2}$ in $\mathrm{MVs}$ changes from $-49.6 \%$ to $+23.1 \%$, showing at least two source of its origin (Figure 6). It is especially interesting nature of isotopically super heavy $\mathrm{CO}_{2}(>+5 \%$ ), which have been controversial for a long time. However, the results of recent studies of ICC in $\mathrm{CO}_{2}$ from petroleum reservoirs revealed their occurrence on the depths not exceeding $2000 \mathrm{~m}$ and related with the oil biodegradation/fermentation at shallow depths [16] (see Figure 6). In [26] were also coming to conclusion, that "oil biodegradation with $\mathrm{CO}_{2}$ reduction likely occurs at a shallower depth along the seepage system of the mud volcano".

Table 1. Dependence between ${ }^{3} \mathrm{He} /{ }^{4} \mathrm{He}$ values and calculated maturity of gases in the Azerbaijan mud volcanoes.

\begin{tabular}{ccccc}
\hline \multirow{2}{*}{ Volcano } & \multicolumn{2}{c}{${ }^{3} \mathbf{H e}{ }^{4} \mathbf{H e}, \mathbf{1 0}^{-\mathbf{8}}$} & & \multicolumn{2}{c}{ Maturity, Req at ICC ethane, \% } \\
\cline { 2 - 5 } & Limits & Average & Limits & Average \\
\hline Group I (main) & $2.8-9.7$ & 6.0 & $1.47-1.71$ & 1.59 \\
Group II & $15-23$ & 19.0 & $1.72-1.77$ & 1.74 \\
Group III & $26-30$ & 27.7 & 2.02 & 2.02 \\
\hline
\end{tabular}



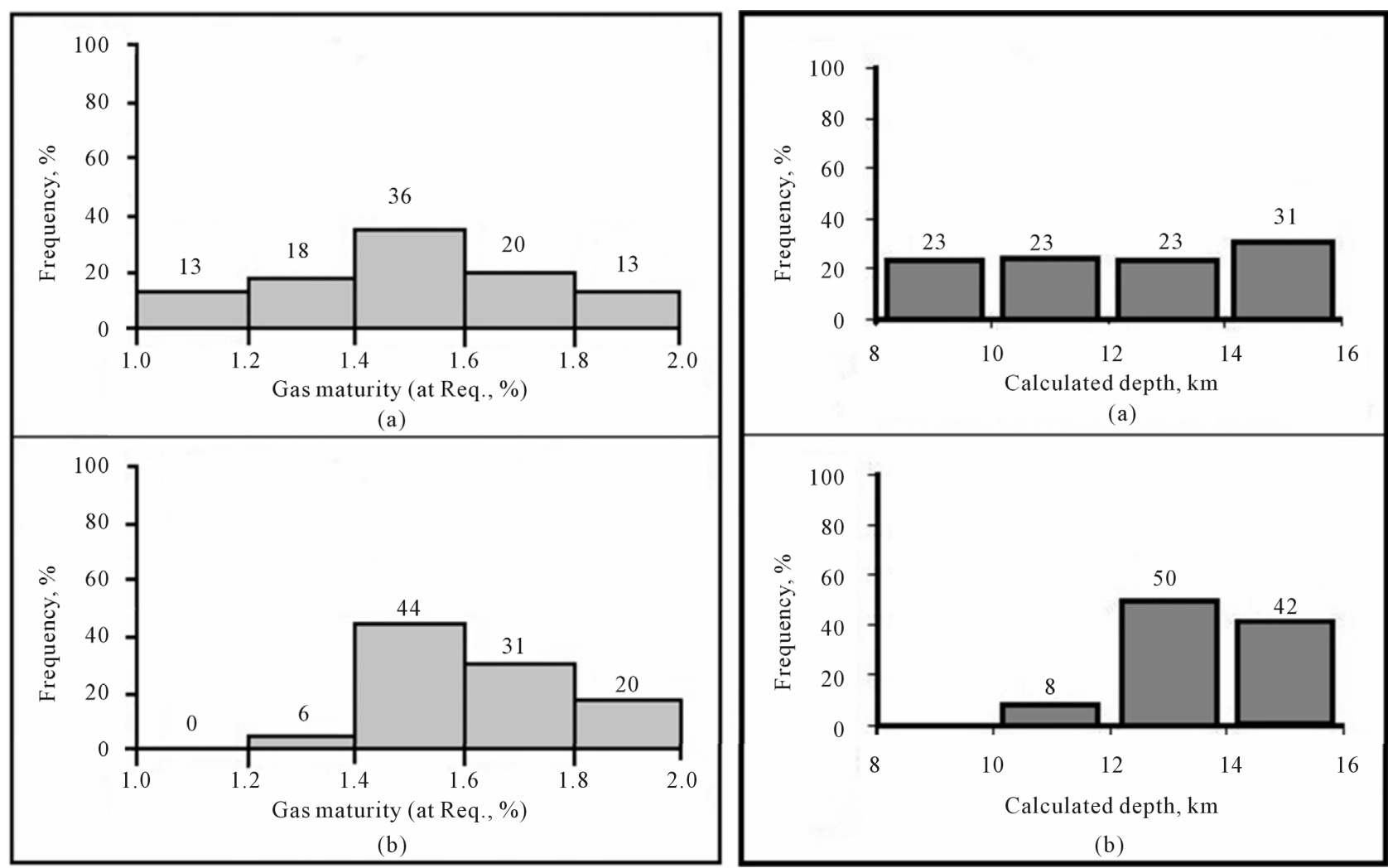

Figure 4. Histograms of distribution of calculated maturity values and source depths of the reservoir (a) and mud volcanic (b) gases in SCB.

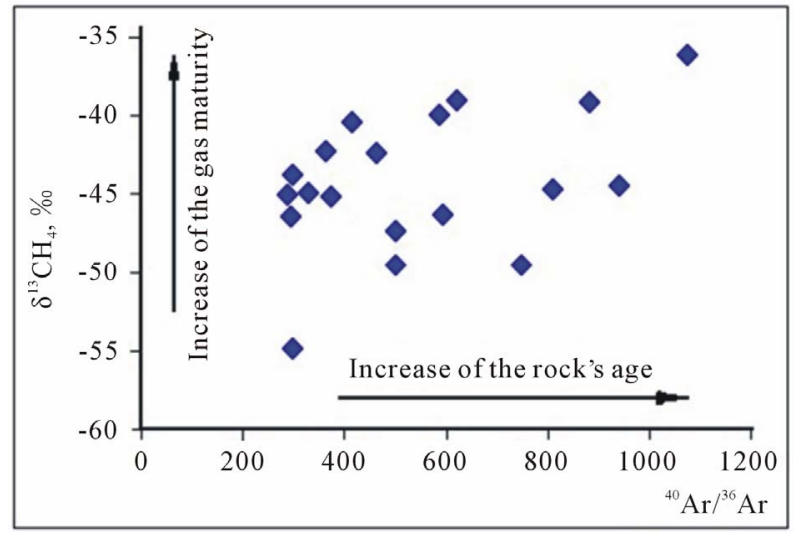

Figure 5. ICC of methane vs ${ }^{40} \mathrm{Ar} /{ }^{36} \mathrm{Ar}$ of the Azerbaijan mud volcanoes.

Existence of several stratigraphic and hypsometric sources of $\mathrm{CH}_{4}$ and $\mathrm{CO}_{2}$ is confirmed by change within wide limits of its ICC from different vents at the same mud volcano (Table 2).

\subsubsection{Gas-Hydrate}

Gas-hydrate accumulation, associated with active submarine mud volcanoes was discovered first time in the Southern Caspian Sea [5]. According to isotope composition of carbon in hydrocarbon gases the gas of gas- hydrate located on Buzdag MV is thermogenic, coming along volcanic channel from deep-sited reservoir towards seabed (Figure 7).

\subsubsection{Oil}

The evaluated maturity of oils on mud volcanoes is lower in comparison with gas. The present day maturity of the MV oils is $0.65 \%-0.80 \%$ in Req. and well agreed with maturity of the reservoir oils (Figure 8). This allows concluding that the MV oils are a product of the destruction of oil accumulation in structures, pierced by MV. Therefore the maximal depth of the MV oils does not exceed depth of corresponding oil reservoir, which according to studied reservoir oils reaches about $4.9 \mathrm{~km}$ in offshore (8 March field, well 580) and $5.3 \mathrm{~km}$ in onshore (Kalamaddyn field, well 3).

The stratigraphic location of the HC sources changes towards regional subsidence of strata (from southern slope of the Great Caucasus to the central deep buried part of SCB) from Mesozoic to Paleogene-Miocene-for gas and from Oligocene to Miocene-for oil $[9,27]$.

\subsubsection{Water}

According to hydrochemical and isotope analyses of the volcanic and formation waters and their correlation they may represent complex mixtures of deep waters 


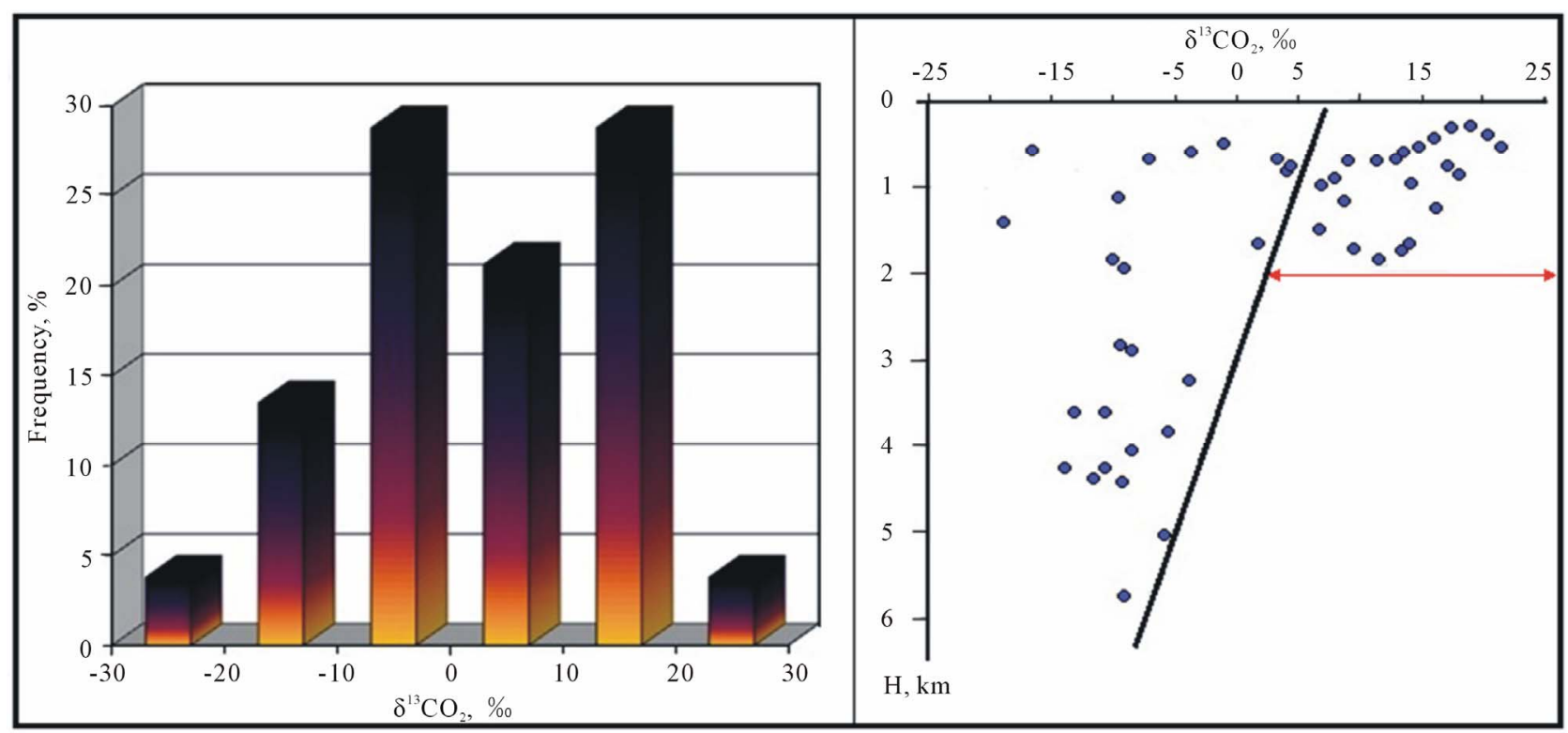

Figure 6. Histogram of distribution of the $\mathrm{ICC}$ of $\mathrm{CO}_{2}$ from mud volcanoes and $\mathrm{ICC}$ of $\mathrm{CO}_{2}$ vs depth for the reservoir gases.

Table 2. Isotope-chemical composition of gases from different vents of the same volcano.

\begin{tabular}{|c|c|c|c|c|c|c|}
\hline MV & $\mathrm{CH}_{4}, \%$ & $\mathrm{C}_{2} \mathrm{H}_{6}+, \%$ & $\mathrm{~N}_{2}, \%$ & $\mathrm{CO}_{2}, \%$ & ${ }^{13} \mathrm{C}_{\mathrm{CH}_{4}}, \% \mathrm{oo}$ & ${ }^{13} \mathrm{C}_{\mathrm{CO}_{2}}, \% \mathrm{oo}$ \\
\hline \multicolumn{7}{|c|}{ Shorbulag: } \\
\hline a) & 75.4 & nd & 23.6 & 1 & -41.5 & 0.5 \\
\hline b) & 96.6 & nd & 1.1 & 2.3 & -50.6 & -26.8 \\
\hline \multicolumn{7}{|c|}{ Melikchobanly: } \\
\hline a) & 84.1 & 0.9 & 2.8 & 12.1 & -45.2 & 20.9 \\
\hline b) & 72.3 & nd & 20.4 & 7.3 & -44.7 & -14 \\
\hline \multicolumn{7}{|c|}{ Cheildag: } \\
\hline a) & 80.3 & nd & 7.8 & 11.9 & -43.3 & 2.4 \\
\hline b) & 91.3 & 3.5 & 2 & 3.2 & -37.3 & 23.1 \\
\hline \multicolumn{7}{|c|}{ Ayrantekan: } \\
\hline a) & 94.4 & 1.4 & 1.3 & 2.3 & -49.8 & -8.1 \\
\hline b) & 85.2 & nd & 13.2 & 1.6 & -47.9 & -0.1 \\
\hline
\end{tabular}

(slightly salty, mainly alkaline and fresh condensate waters) and relatively shallower brines (predominantly chlorine) or meteoric waters. This corresponds to the results of other investigations [26,28-30].

\subsubsection{Mud}

There are complex monitoring indices proving shallow origin of the mud, erupted by MVs. They are the following:

\subsubsection{Rock Compaction Criterion}

Depending on a geological history of development, normal and non-equilibrium compaction of sediments occurs in various basins of the world. Therefore the intensity of the worldwide sediments compaction changes over a wide range (especially within $0-2 \mathrm{~km}$ ). Below the depth of about $3 \mathrm{~km}$ rate of compaction is minimized and stabilized. This allows concluding that the sediments and, especially clays, undergo the greatest compaction (up to $60 \%-70 \%$ of the initial volume) in the interval of $0-4 \mathrm{~km}$ depths during the subsidence of any basin. It is mean that clays reaching the depth of $3-4 \mathrm{~km}$ lose the large part of sediment waters. The loss of waters by the clay leads to decreasing of its plasticity and mobility and therefore the focus of the clayey diapir formation, most probably, occurs at the depth not greater than $4 \mathrm{~km}$. Bulk of clayey breccia erupted by the mud volcano is predominantly connected with this interval of depths. It is suggested a shallow occurrence of mud chamber on the Lokbatan mud volcano [31].

Results of investigations of MVs in northern Italy [24] well correspond to this statement. They came to conclusion, that mud is younger and shallower (about $1 \mathrm{~km}$ ) than methane released by MVs from deep Miocene deposits and Mesozoic carbonate source rocks. In [32] under the maturity data depth of a mud mobilization about 


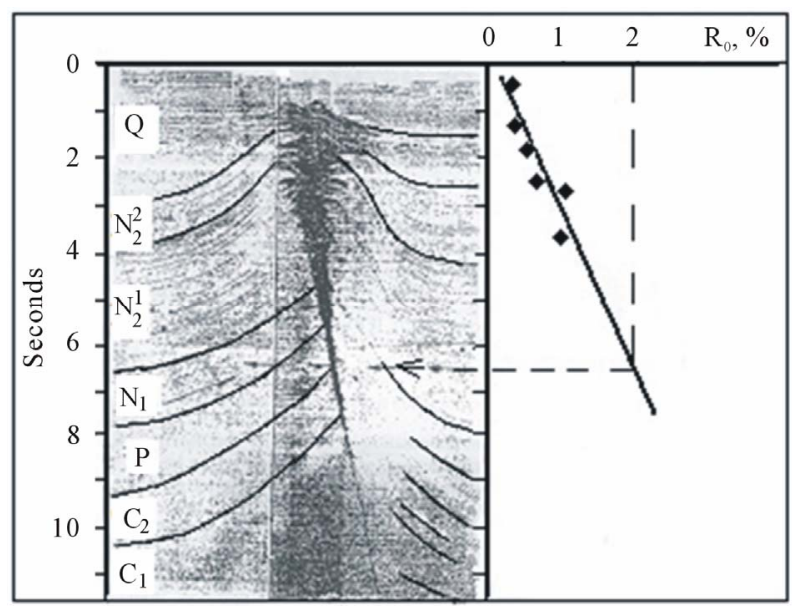

Figure 7. Fragment of the seismic time section across Buzdag submarine mud volcano in the Southern Caspian Sea with calculated depth of location of the gas source of gas hydrate.

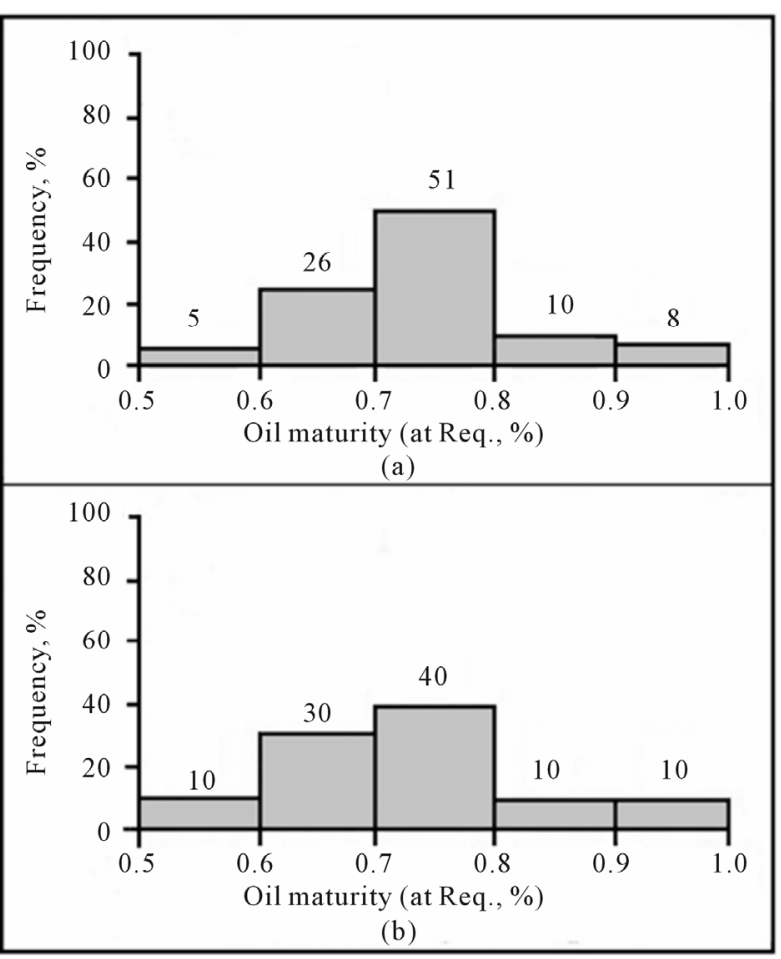

Figure 8. Histograms of distribution of maturity values of the reservoir (a) and mud volcanic (b) oils (at Req., calculated on MPI-1).

\section{$1.7 \mathrm{~km}$ was estimated.}

\subsubsection{Temperature Criterion}

Geothermal measurements on Lokbatan MV had started three days after the eruption in October 2001 and continued for about 7 month [7,8]. The temperature variations at depths of $0.5,1.0$, and $1.5 \mathrm{~m}$ following the Lokbatan mud volcano eruption are shown on Figure 9. The temperature of erupted mud, on the first day attained about

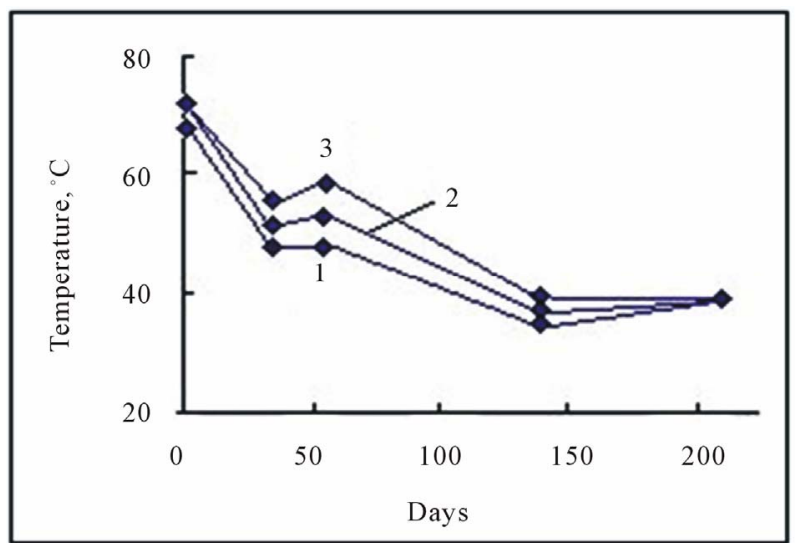

Figure 9. The change of mud temperature after eruption of Lokbatan mud volcano in 2000: at depths of (1) 0.5 ; (2) 1.0 ; and (3) $1.5 \mathrm{~m}$.

$70^{\circ} \mathrm{C}$ at all measured levels. The observations revealed a continuously decrease temperature and its stabilization about 150 days after eruption (due to cooling of the mud). The temperature of the liquid mud in the crater of the Touragay volcano was $43^{\circ} \mathrm{C}$ after six days of eruption. According to the assumed temperature gradient $20^{\circ} \mathrm{C} / \mathrm{km}$ calculated maximal depth occurrence of the mud source is about $3.5 \mathrm{~km}$.

\subsubsection{Seismic Records of the Mud Volcano Eruptions and the Eyewitness Evidences}

Eruptions of mud volcanoes, like magmatic volcanoes, are followed by local ground oscillations. Unfortunately these oscillations are documented only by regional seismic network; there is no special direct (or close) local seismic monitoring on mud volcano.

At least, the existence of two phases of mud volcano eruption was established on the basis of seismic records. The hypocenter of the relatively weak first phase of earth tremors corresponds to the depths of approximately 2 - 3 $\mathrm{km}$ and is related with the outflow to the surface of the fluidized clayey mass. As a result the effusion of mud disrupted the established dynamic equilibrium in the volcano channel, which provokes ejection of gas and fragments of rocks from the depth of approximately 12 $\mathrm{km}$ to the surface. The eruption of gas is accompanied by the second energetically more powerful phase of earth tremors.

This two-phase process of eruption agrees well with the observations of eyewitnesses indicating that initial rise of the breccia mass covering volcano was followed by eruption of fresh mud. The second phase of eruption began with the strong subsurface roar, which was precursor to a powerful eruption of gas.

\subsubsection{Rock-Ejections}

Maturity of the Paleogene-Neogene rock-ejection var- 
ies in range of $0.71 \%-1.49 \%$ Ro (Table 3 ), which corresponds to the depth interval of $5.5-14.5 \mathrm{~km}$ (Figure 10).

The estimated depth occurrence of the mud volcanoes rock-ejections is commensurable with the depth occurrence of gas. As a rule rock fragments are blown out to the earth surface simultaneously with erupted gas, both of which originated from the same feeding source.

\subsection{The Mud Volcano Modeling}

Despite the numerous studies, the mechanism controlling mud volcano formation and activity has not been studied adequately and it is still debatable. But attempts to create a model of a mud volcano formation have

Table 3. Vitrinite reflectance data of the mud volcanoes rockejections, SCB.

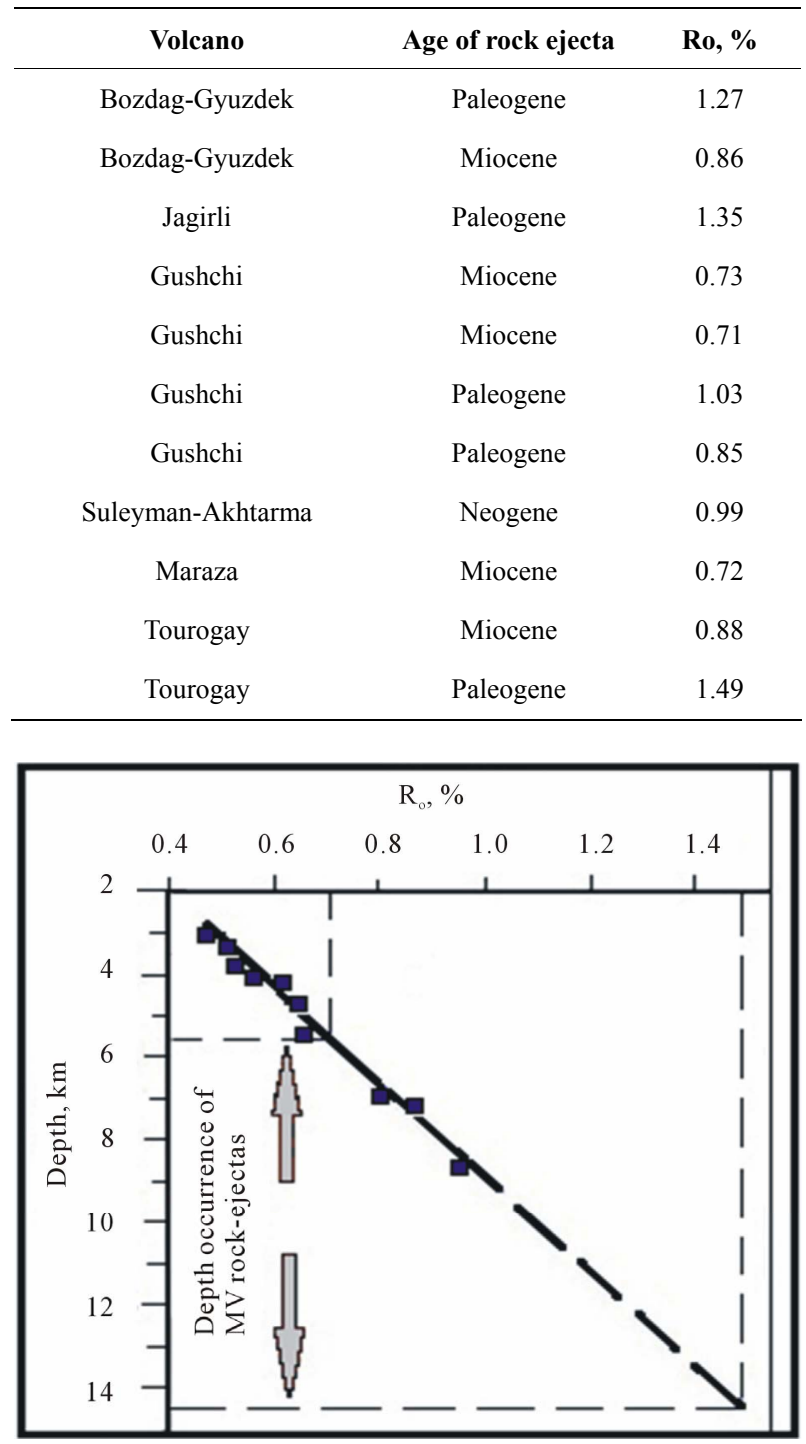

Figure 10. Estimation of the depth occurrence of the mud volcanic rock-ejectas, based on its maturity degree and paleotemperature model of the SCB. already been made by some researchers [10,29,30,33 etc.].

Gravitational modeling on the Lokbatan, AkhtarmaPuta and Qushkhana mud volcanoes in Azerbaijan indicates the presence of decompacted mud in $2-3 \mathrm{~km}$ depth interval [10] (Figure 11).

These mud volcano localities are characterized by considerable non-tidal variations of gravitational field. The relationship between gravitational anomaly values and activity of these mud volcanoes has been revealed: volcanoes having higher eruption frequency have larger gravitational anomaly values (e.g. Lokbatan MV), whereas lower values of the inactive volcanoes (e.g. Qushkhana MV) are noted.

According to mud volcano model [29] in deep sedimentary strata (at depths below $10 \mathrm{~km}$ ) the supercritical state of water plays significant role in formation of mud volcanoes. Under these conditions dramatic decrease of water density initiates a vapor-driven upward migration process with subsequent condensation of water at shallow depths. The authors believe that such a mechanism

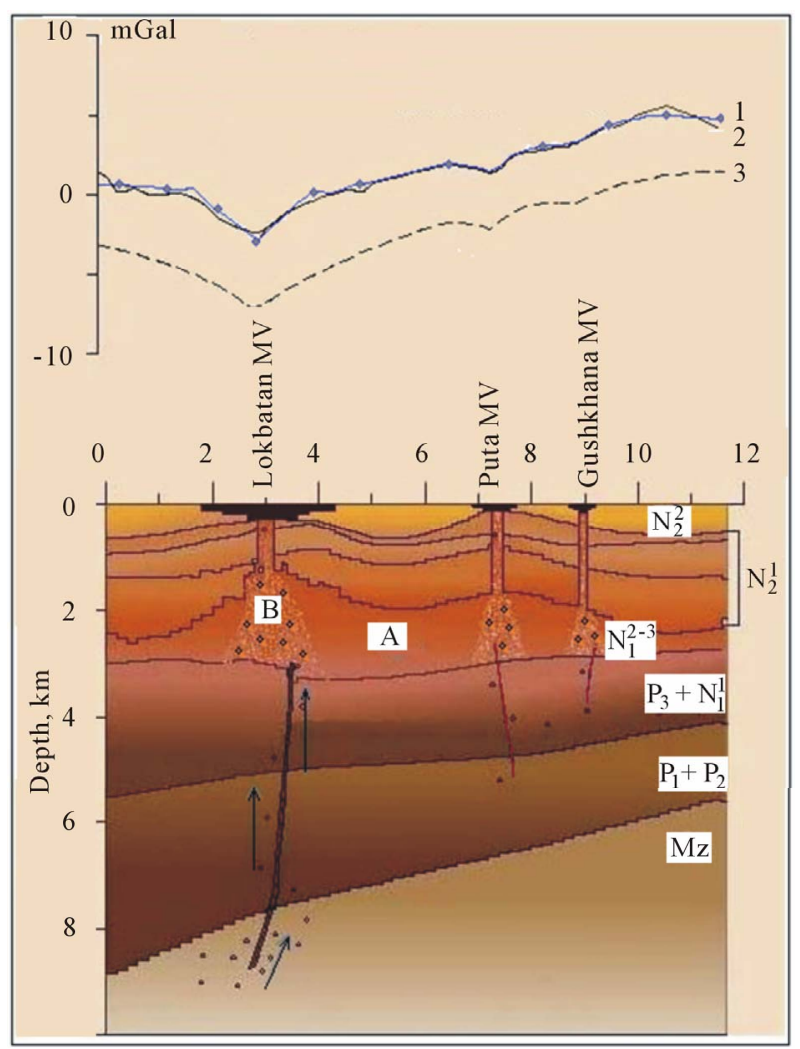

Figure 11. Model of the mud volcano formation, based on results of gravity survey over Lokbatan (erupted 22 times)-Puta (erupted 1 time)-Gushkhana (not erupted) mud volcanoes: A. Plastic clayey bed; B. Fluidized, undercompacted (low dense) and metastable clayey mass; 1 . Observed gravity anomaly; 2. Computed gravity anomaly from initial model; 3 . Selected configuration and density of rocks. Arrows are showed upward migration of deep overpressured gas-vapor mixture. 
give an explanation of subvertical mass transfer associated with mud volcanoes.

\section{CONCLUSIONS}

MVs are characteristic to young non-equilibrium basins with rapidly subsiding, high sedimentation rate and great thickness of sedimentary cover. Formation of diapirs/mud volcanoes happen as a result of accumulation of critical energy in overpressured mud volcanoes system and violation of equilibrium in this system provoked by seismicity, tide waves, etc. The primary mechanism of the upward flow of plastic mud (mud diapir formation) is a reaction to buoyancy forces caused by the bulk density contrast between overpressured decompacted mud at depth and the overlying deposits of greater density.

According to studies of the isotopic composition of helium, argon and carbon in methane the Azerbaijan mud volcanoes have a sedimentary origin and they are products of different stages of a single process of hydrocarbon generation within the sedimentary succession. The chemical and isotopic signatures of MV gases are predominantly thermogenic with some admixture of microbial methane.

On the ground of the complex isotope-geochemical, temperature and other criterions the difference of the source depth of the liquid, gaseous and solid products of MVs has been established. The gases and rock fragments (rock-ejections) have the deepest roots (within depth interval of $5-15 \mathrm{~km}$ ). Overpressured gas is the main force in formation and activity of MVs. But origin of MV gases is remaining debatable, because the methane can be derived from both organic-reach mud (primary accumulations in sand interlayer within source rocks) and from larger reservoirs just above or just below such shales.

MV oils are product of destruction of oil accumulations in reservoirs pierced by volcanoes. Therefore, source of MV oils is thought to be limited by the depth of associated oil reservoirs, which in the studied region does not exceed $5.5 \mathrm{~km}$.

The source of the fluidized clayey mass does not exceed $3-4 \mathrm{~km}$. It is confirmed by qravitational modeling on some mud volcanoes in Azerbaijan, which indicates the presence of decompacted mud in $2-3 \mathrm{~km}$ depth interval.

According to seismic records of volcanic earthquakes and the eyewitnesses two-phase mechanism of MV eruptions occurs. The first phase is related to outflow of mud from depth of $2-3 \mathrm{~km}$ and the next more powerful phase -with blowout of the overpressured gas (predominantly methane with admixture of its gaseous and liquid homologues, produced in deeply buried, organic-rich sediments). As a rule rock fragments are blown out to the earth surface simultaneously with erupted gas, both of which originated from the same feeding source.

\section{ACKNOWLEDGEMENTS}

The results presented in this paper are based on many field studies on mud volcanoes fulfilled in cooperation with my colleagues from Azerbaijan and other countries. All of them are greatly thanked.

\section{REFERENCES}

[1] Yakubov, A., Ali-Zade, A. and Zeinalov, M. (1971) Mud volcanoes of the Azerbaijan Republic. Nafta Press, Baku (in Russian).

[2] Aliyev, A.A. and Kabulova, A.Y. (1980) Isotope of helium in gases of mud volcanoes in Azerbaijan. Reports of the Azerbaijan National Academy of Sciences, 36, 52-56 (in Russian).

[3] Valyaev, B.M., Grinchenko, Y.I., Erokhin, V.E., Prokhorov, V.S. and Titkov, G.A. (1985) Isotopic composition of gases from mud volcanoes. Lithology and Minerals, 20, 62-75 (in Russian).

[4] Rakhmanov, R.R. (1987) Mud volcanoes and their implications for oil and gas prediction. Nedra, Moscow (in Russian).

[5] Ginsburg, G.D., Guseynov, R.A., Dadashev, A.A., Ivanova, G.A., Kazantsev, S.A., Solovyev, V.A., Telepnev, E.V., Askeri-Nasirov, R.Ye., Esikov, A.D., Maltseva, V.I., Mashirov, Yu.G. and Shabayeva, I.Yu. (1992) Gas hydrates of the Southern Caspian. International Geology Review, 34, 765-782. doi:10.1080/00206819209465635

[6] Guliyev, I.S. and Feyzullayev, A.A. (1996) Geochemistry of hydrocarbon seepages in Azerbaijan. In: Shumacher, D. and Abrams M., Eds., Hydrocarbon Migration and Its Near-Surface Expression, AAPG Memoir, 66, 63-70.

[7] Mukhtarov, A., Kadirov, F., Guliyev, I., Lerche, I. and Feyzullayev, A. (2003) Temperature variations in the Lokbatan mud volcano crater (Azerbaijan) after the eruption in 25 October 2001. Energy Exploration and Exploitation, 21, 187-207. doi:10.1260/014459803769520043

[8] Kadirov, F.A. and Mukhtarov, A.Sh. (2004) Geophysical fields, deep structure and dynamics of the Lokbatan mud volcano. Fizika Zemli, 40, 327-333 (in Russian).

[9] Guliyev, I.S., Feyzullayev, A.A. and Husseynov, D.A. (2004) Geochemical features and source of fluids of mud volcanoes in South Caspian basin in lights of new data at isotopes C, H, and O. Geochimiya, 7, 792-800 (in Russian).

[10] Feyzullayev, A.A., Kadirov, F.A. and Aliyev, Ch.S. (2005) Mud volcano model resulting from geophysical and geochemical research. In: Martinelli G. and Panahi B., Eds., Mud Volcanoes, Geodynamics and Seismicity, Springer, Berlin, 251-261. doi:10.1007/1-4020-3204-8_23

[11] Guliyev, I.S., Feyzullayev, A.A., Aliyev, A.A. and Movsumova, U.A. (2005) Composition of gases and organic matter of rocks ejecta of mud volcanoes in Azerbaijan. Geologiya nefti i Gaza, 3, 27-30 (in Russian). 
[12] Isaksen, G., Aliyev, A., Guliyev, I., Barboza, S. and Puls, D. (2007) Regional evaluation of source rock quality in Azerbaijan from the geochemistry of organic-rich rocks in mud-volcano ejecta. AAPG Special Volumes, 51-64.

[13] Mellors, R., Kilb, D., Aliyev, A., Gasanov, A. and Yetirmishli, G. (2007) Correlations between earthquakes and large mud volcano eruptions. Journal of Geophysical Research, 112, B04304. doi:10.1029/2006JB004489

[14] Etiope, G., Feyzullayev, A.A., Milkov, A.V., Waseda, A., Mizobe, K. and Sun, C.H. (2009) Evidence of subsurface anaerobic biodegradation of hydrocarbons and potential secondary methanogenesis in terrestrial mud volcanoes. Marine and Petroleum Geology, 26, 1692-1703. doi:10.1016/j.marpetgeo.2008.12.002

[15] Kopf, A., Stegmanna, S., Delisle, G., Panahic, B., Aliyev, C. and Guliyev, I. (2009) In situ cone penetration tests at the active Dashgil mud volcano, Azerbaijan: Evidence for excess fluid pressure, updoming, and possible future violent eruption. Marine and Petroleum Geology, 26, 17161723. doi:10.1016/j.marpetgeo.2008.11.005

[16] Feyzullayev, A.A. and Movsumova, U.A. (2010) The nature of the isotopically heavy carbon composition of carbon dioxide and bicarbonates in the waters of mud volcanoes in Azerbaijan. Geochemistry International, 48, 517522. doi:10.1134/S0016702910050083

[17] Philip, H., Cisternas, A., Gvishiani, A. and Gorshkov, A. (1989) The Caucasus: An actual example of the initial stages of continental collision. Tectonophysics, 161, 1-21. doi:10.1016/0040-1951(89)90297-7

[18] Axen, G.J., Lam, P.S., Grove, M. and Stockli, D.F. (2001) Exhumation of the west-central Alborz mountains, Iran, Caspian subsidence, and collision-related tectonics. Geology, 29, 559-562.

doi:10.1130/0091-7613(2001)029<0559:EOTWCA $>2.0$. $\underline{\mathrm{CO} ; 2}$

[19] Jackson, J.K., Priestley, K., Allen, M.B. and Berberian, M. (2002) Active tectonics of the South Caspian Basin. Geophysical Journal International, 148, 214-245.

[20] Guliyev, I.S., Kadirov, F.A., Reilinger, R.E., Gasanov, R.I. and Mamedov, A.R. (2002) Active tectonics in Azerbaijan based on geodetic, gravimetric, and seismic data. Earth Science Section, 383, 174-177.

[21] Feyzullayev, A.A. (2010) Physik-chemical interaction in the rock-fluid system in connection with ontogenesis of oil and gas (an example of the South Caspian basin). News of ANAS, Earth Sciences Series, 4, 28-45 (in Russian).

[22] Faber, E.Z. (1987) Isotopengeochemie gasformiger Kohlenwasserstoffe. Erdole, Erdgas and Kohle, 103, 210-218 (in German).

[23] Peters, K. and Moldovan, J. (1993) The biomarker guide: Interpreting molecular fossils in petroleum and ancient sediments. Prentice Hall, Englewood Cliffs.

[24] Capozzi, R. and Picotti, V. (2002) Fluid migration and origin of a mud volcano in the Northern Apennines (Italy): The role of deeply rooted normal faults. Terra Nova, 14, 363-370. doi:10.1046/j.1365-3121.2002.00430.x

[25] Mattavelli, L., Ricchiuto, T., Grignani, D. and Schoell, M. (1983) Geochemistry and habitat of natural gases in Po basin, Northern Italy. AAPG Bulletin, 67, 2239-2254.

[26] Nakadaa, R., Takahashia, Y., Tsunogaib, U., Zhengc, G., Shimizua, H. and Hattorid, K. (2011) A geochemical study on mud volcanoes in the Junggar Basin, China. Applied Geochemistry, 26, 1065-1076. doi:10.1016/j.apgeochem.2011.03.011

[27] Feyzullayev, A.A. and Aliyeva, Es.A. (2003) Estimation of the various source rocks contribution in oil pools formation. Proceedings of EAGE 65 Conference and Exhibition, Stavanger, 2-5 June 2003.

[28] Planke, S., Svensen, H., Hovland, M., Banks, D.A. and Jamtveit, B. (2003) Mud and fluid migration in active mud volcanoes in Azerbaijan. Geo-Marine Letters, 23, 258-268. doi:10.1007/s00367-003-0152-Z

[29] Hovland, M., Ruesletten, H., Lifhseth, H., Fichler, C. and Johnsen, H. (2006) Mud volcanoes-A result of supercritical water formation at depth? Proceedings of AAPG/ GSTT Hedberg Conference Mobile Shale Basins-Genesis, Evolution and Hydrocarbon Systems, Trinidad and Tobago, 4-7 June 2006.

[30] Mazzini, A. (2009) Mud volcanism: Processes and implications. Marine and Petroleum Geology, 26, 1677-1680. doi:10.1016/j.marpetgeo.2009.05.003

[31] Cooper, C. (2001) Mud volcanoes of Azerbaijan visualized using 3D seismic depth cubes: The importance of overpressured fluid and gas instead of non extant diapirs. Proceedings of Subsurface Sediment Mobilization Conference, Ghent, 10-13 September 2001.

[32] Kopf, A., Robertson, A.H. and Volkmann, N. (2000) Origin of mud breccia from the Mediterranean ridge accretionary complex based on evidence of maturity of organic matter and related petrographic and regional tectonic evidence. Marine Geology, 166, 65-82. doi:10.1016/S0025-3227(00)00009-8

[33] Arafin, S. (2005) Three-dimensional gravity modeling of a Trinidad mud volcano. West Indies Exploration Geophysics, 36, 329-333. doi:10.1071/EG05329 